February - 2009

\title{
Research and Practice in K-12 Online Learning: A Review of Open Access Literature
}

\author{
Cathy S. Cavanaugh \\ University of Florida, USA \\ Michael K. Barbour \\ Wayne State University, USA \\ Tom Clark \\ TA Consulting, Illinois, USA
}

\begin{abstract}
The literature related to online learning programs for K-12 students dates to the mid-1990s and builds upon a century of research and practice from K-12 distance education. While K-12 online learning programs have evolved and grown over the past decade, the amount of published research on virtual schooling practice and policy is limited. The current literature includes practitioner reports and experimental and quasi-experimental studies, both published and unpublished. This paper reviews open access literature in K-12 online learning and reports on a structured content analysis of the documents. Themes in the literature include steady growth and a focus on the benefits, challenges, and broad effectiveness of K-12 online learning. In addition, newly developed standards for K-12 online learning are emerging in descriptions of effective practices.
\end{abstract}

\section{Introduction}

In North America and other industrialized countries, distance education for elementary and secondary students is seen as a solution to several educational problems, including crowded schools, a shortage of secondary courses for remedial or accelerated students, a lack of access to qualified teachers in a local school, and the challenge to accommodate students who need to learn at a pace or in a place different from a school classroom (Cavanaugh \& Clark, 2007). In less industrialized nations, K-12 online education is seen as a social and economic development strategy (Moore \& Kearsley, 2005). Thus, it is clear why K-12 distance education programs are developing rapidly around the world and why growth in K-12 online course enrollments has outstripped that of other educational formats in recent years (Setzer \& Lewis, 2005). A 
fundamental challenge in this relatively new educational field for program developers, managers, and instructors is locating guidance from successful practice and from research and literature.

Online learning is a form of distance education whose central defining characteristic is the separation of teacher and learner (Keegan, 1996). Watson, Winograd, and Kalmon (2004) defined online learning as "education in which instruction and content are delivered primarily via the Internet" (p. 95). Many K-12 online learning programs in North American are referred to as virtual schools. Clark (2001) defined a virtual school as "an educational organization that offers K-12 courses through Internet- or Web-based methods" (p. 1). The literature related to online learning programs for K-12 students began to grow in the mid-1990s, building upon a century of research and practice from K-12 distance education (Clark, 2003; Edelson \& Pitman, 2001). Although K-12 online learning programs have evolved and grown over the past decade, there is a limited amount of published research on virtual schooling practice (Barbour \& Reeves, 2009). The current literature includes practitioner reports and experimental and quasi-experimental studies, both published and unpublished.

The authors reviewed the existing open access literature in K-12 online learning and report on a structured content analysis of selected documents. Previous reviews of the research on K-12 online learning have used both qualitative and quantitative methods (Cavanaugh, 2001; Cavanaugh, 2004; Rice, 2006; Smith, Blomeyer \& Clark, 2005). These reviews were limited to dozens of studies and reports, compared to recent reviews of the literature on adult online learning, which included hundreds of studies (e.g., Machtmes \& Asher, 2000; Allen, et al., 2002; Bernard, et al., 2003; Shachar \& Neumann, 2003; Ungerleider \& Burns, 2003). As an example of the growth in the published literature in K-12 online learning, of 226 publications that were reviewed for this paper and published since 1997, 29 were published during the first three years of that period and 69 were published since 2006.

The findings of the previous reviews were limited to generalizations about broad effectiveness because insufficient data were available to substantiate analysis of factors that contributed to effectiveness. However, the picture is changing as data from the first ten years of virtual schooling have become available. This paper moves beyond the blanket endorsements of the effectiveness of virtual schooling to examine the themes that are prevalent in the open access documents published online from 1997 to July 2008. Examining these themes revealed the emphases in virtual schooling research as well as the needs for future study.

\section{Literature Review}

To date, the amount of research evidence in refereed journal publications and papers from refereed conferences in the field of virtual schooling is limited (DiPietro, Ferdig, Black, \& Preston, 2008). Much of the published literature is based upon the personal experiences of those involved in the practice of virtual schooling; as well, much of the research is available only in unpublished masters' theses and doctoral dissertations. In many ways, this is indicative of the foundational descriptive work that often precedes experimentation in any scientific field. In other 
words, it is important to know how students in virtual schools engage in their learning in this environment prior to conducting any rigorous examination of virtual schooling.

Expanding upon his definition of a virtual school, Clark (2001) indicated that there were different types of virtual schools, which he categorized in seven ways (see Table 1).

\section{Table 1}

Clark's Seven Categories of Virtual Schools

\begin{tabular}{|l|l|}
\hline Type & Description \\
\hline $\begin{array}{l}\text { State-sanctioned, state- } \\
\text { level }\end{array}$ & $\begin{array}{l}\text { Virtual schools operating on a state-wide level, such as the Florida } \\
\text { Virtual School }\end{array}$ \\
\hline $\begin{array}{l}\text { College and university- } \\
\text { based }\end{array}$ & $\begin{array}{l}\text { Independent university high schools or university-sponsored } \\
\text { delivery of courses to K-12 students, such as the University of } \\
\text { California College Prep Online (UCCP). }\end{array}$ \\
\hline $\begin{array}{l}\text { Consortium and } \\
\text { regionally-based }\end{array}$ & $\begin{array}{l}\text { Virtual schools operated by a group of schools or school districts, } \\
\text { such as the Virtual High School (VHS) }\end{array}$ \\
\hline $\begin{array}{l}\text { Local education agency- } \\
\text { based }\end{array}$ & $\begin{array}{l}\text { Virtual schools operated by a single school or school district, such } \\
\text { as the Gwinnett County Online Campus. }\end{array}$ \\
\hline $\begin{array}{l}\text { Virtual charter schools } \\
\text { Virtual schools created under the charter school legislation in many } \\
\text { states, such as Connections Academy, also commonly known as } \\
\text { cyberschools. }\end{array}$ \\
\hline $\begin{array}{l}\text { Private virtual schools } \\
\text { For-profit providers of } \\
\text { curricula, content, tools } \\
\text { and infrastructure }\end{array}$ & $\begin{array}{l}\text { Virtual schools that are operated in the same manner as a brick and } \\
\text { mortar private school, such as the Christa McAuliffe Academy. } \\
\text { of course materials, such as APEX Learning. }\end{array}$ \\
\hline
\end{tabular}

Watson, Winograd, and Kalmon (2004) offered a slightly different classification consisting of five types of virtual school, which were summarized by Rice (2006) in Table 2.

Table 2

Watson, Winograd, and Kalmon's Five Categories of Virtual Schools (p. 427)

\begin{tabular}{|l|l|}
\hline Type & Description \\
\hline $\begin{array}{l}\text { Statewide supplemental } \\
\text { programs }\end{array}$ & $\begin{array}{l}\text { Students take individual courses but are enrolled in a physical } \\
\text { school or cyber school within the state. These programs are } \\
\text { authorized by the state and overseen by state education governing } \\
\text { agencies. }\end{array}$ \\
\hline District-level & Are typically operated by autonomous districts and are typically \\
\hline
\end{tabular}




\begin{tabular}{|l|l|}
\hline supplemental programs & not tracked by state agencies. \\
\hline $\begin{array}{l}\text { Single-district cyber } \\
\text { schools }\end{array}$ & $\begin{array}{l}\text { Provide an alternative to the traditional face-to-face school } \\
\text { environment and are offered by individual districts for students } \\
\text { within that district. }\end{array}$ \\
\hline $\begin{array}{l}\text { Multi-district cyber } \\
\text { schools }\end{array}$ & $\begin{array}{l}\text { Are operated within individual school districts but enroll students } \\
\text { from other school districts within the state. This represents the } \\
\text { largest growth sector in K-12 online learning. }\end{array}$ \\
\hline Cyber charters & $\begin{array}{l}\text { Are chartered within a single district but can draw students from } \\
\text { across the state. }\end{array}$ \\
\hline
\end{tabular}

Barker, Wendel, and Richmond (1999) provided a similar but more exclusive definition of a virtual school as "one that offers the mandated provincial instructional program to students through web-based means (i.e., computer-mediated and online via the Internet" (p. 2). In the full description, Barker et al. stated that a virtual school was one where students were enrolled fulltime in the virtual environment. According to this definition, most statewide virtual schools (such as the Florida Virtual School (FLVS)) and the longstanding Virtual High School Global Consortium (VHS) only provided virtual schooling opportunities, but were not virtual schools. Within the literature, Clark's definition has been generally accepted.

It should be understood that there is a great deal of variety in the different types of virtual schools that currently operate in North America, and virtual schooling is primarily a North American phenomenon (Cavanaugh, Ferdig, Johnson, Lowes, Smith, \& Blomeyer, 2006). Powell and Patrick (2006) found that while many other countries operate some form of Web-based or online curricular support program for students and teachers (e.g., a SchoolNet such as the one found at http://www.schoolnet.org.uk/), and some even offer Web-based or online distance education programs, of the 30 countries surveyed, only Canada and the United States operate entities that can be classified as virtual schools. In fact, Australian Glenn Russell is one of the few scholars outside of North America who has written about virtual schooling (e.g., Russell, 2001, 2006b).

Barbour and Reeves (2009) have classifed virtual schooling literature as outlining the benefits of virtual schooling or describing the difficulties or challenges of virtual schooling. They argued that the benefits could be divided into five main areas: expanding educational access, providing high quality learning opportunities, improving student outcomes and skills, allowing for educational choice, and achieving administrative efficiency (see Table 3).

\section{Table 3}

Benefits of Virtual Schooling (Barbour and Reeves, 2009, p. 409)

\begin{tabular}{|l|l|}
\hline Benefit & Selected References \\
\hline Higher levels of motivation & Kellogg and Politoski (2002) \\
\hline Expanding educational access & Berge \& Clark (2005); Cavanaugh (2001); \\
\hline
\end{tabular}




\begin{tabular}{|c|c|}
\hline & $\begin{array}{l}\text { Freedman, Darrow, Watson, \& Lorenzo (2002); } \\
\text { Fulton (2002b); Hernandez (2005); Kellogg \& } \\
\text { Politoski (2002); Zucker (2005) }\end{array}$ \\
\hline $\begin{array}{lll}\begin{array}{l}\text { Providing } \\
\text { opportunities }\end{array} & \text { high-quality } & \text { learning } \\
\end{array}$ & $\begin{array}{l}\text { Berge \& Clark (2005); Butz (2004); Elbaum \& } \\
\text { Tinker (1997); Fulton (2002a); Kaplan-Leiserson } \\
\text { (2003); Kellogg \& Politoski (2002); Thomas (1999; } \\
\text { 2000; 2003); Tinker \& Haavind (1997) }\end{array}$ \\
\hline Improving student outcomes and skills & Berge \& Clark (2005); Zucker \& Kozma (2003) \\
\hline Allowing for educational choice & $\begin{array}{l}\text { Baker, Bouras, Hartwig, \& McNair (2005); Berge } \\
\& \text { Clark (2005); Butz (2004); Fulton (2002b); } \\
\text { Hassell \& Terrell (2004) }\end{array}$ \\
\hline Administrative efficiency & Keeler (2003); Russo (2001); Vail (2001) \\
\hline
\end{tabular}

However, whether these benefits are realized through virtual schooling remains in doubt in the minds of some critics, and the research to support these conjectures is limited.

Along with the benefits, there were a number of challenges associated with virtual schooling. Barbour and Reeves described these challenges as the high start-up costs associated with virtual schools, access issues surrounding the digital divide, the approval or accreditation of virtual schools, and student readiness and retention issues (see Table 4).

\section{Table 4}

Challenges of Virtual Schooling (Barbour and Reeves, 2009, p. 111)

\begin{tabular}{|l|l|}
\hline Challenge & Selected References \\
\hline $\begin{array}{l}\text { High start-up costs associated with virtual } \\
\text { schools }\end{array}$ & Cavalluzzo (2004); Morris (2002) \\
\hline $\begin{array}{l}\text { Access issues surrounding the digital } \\
\text { divide }\end{array}$ & Hernandez (2005) \\
\hline $\begin{array}{l}\text { Approval or accreditation of virtual } \\
\text { schools }\end{array}$ & Berge \& Clark (2005) \\
\hline $\begin{array}{l}\text { Student readiness issues and retention } \\
\text { issues }\end{array}$ & $\begin{array}{l}\text { Ballas \& Belyk (2000); Barker \& Wendel (2001); } \\
\text { Berge and Clark (2005); Bigbie \& McCarroll } \\
(2000) ; \text { Cavanaugh, Gillan, Bosnick, Hess, \& Scott } \\
\text { (2005); Clark, Lewis, Oyer, \& Schreiber (2002); } \\
\text { Espinoza, Dove, Zucker, \& Kozma (1999); } \\
\text { Haughey \& Muirhead (1999); Kozma, Zucker, \& } \\
\text { Espinoza (1998); McLeod, Hughes, Brown, Choi, } \\
\text { \& Maeda (2005); Zucker \& Kozma (2003) }\end{array}$ \\
\hline
\end{tabular}


The literature that reports research on virtual schooling tends to fall into one of two categories: research into the effectiveness of virtual schooling (see Barbour \& Mulcahy, 2006, 2008; Cavanaugh, 2001; Cavanaugh et al., 2005) and student readiness and retention issues (those studies listed in Table 4 under the heading "Student readiness issues and retention issues"). Over the past decade, several studies have shown that the only students who were typically successful in online learning environments were those who had independent orientations towards learning, who were highly motivated by intrinsic sources, and who had strong time management, literacy, and technology skills (Cavanaugh, 2007). These characteristics are consistent with traits that are typically associated with adult learners. The problem with this focus is that adults learn differently from children and adolescents (Bright, 1989; Cavanaugh et al., 2004; Knowles, 1970; Moore, 1973; Vygotsky, 1962, 1978). This supposition has led to the call for more research into the factors that account for K-12 student success in online learning.

\section{Methodology}

Qualitative metasynthesis involves synthesizing literature to provide an overall perspective on a given topic or issue (Thorne, Jensen, Kearney, Noblit, \& Sandelowski, 2004). The authors used a type of metasynthesis called template analysis, which entailed designing a template for the coding of the literature ( $\mathrm{Au}, 2007)$. For our metasynthesis, the literature about K-12 virtual education was collected from systematic searches of refereed conference proceedings, refereed journals, dissertation indexes, and reports in the education press. A significant portion of the research and reporting on K-12 distance education hadbeen conducted by public and private research centers (e.g., the North Central Regional Educational Laboratory or the Appalachian Technology in Education Consortium), which required the authors to search the World-Wide Web using the Google ${ }^{\circledR}$ search engine and Google ${ }^{\circledR}$ Scholar. Search terms included but were not limited to the following: virtual school, cyberschool, K-12 online learning and distance education, web-based learning, and e-learning. Our analysis was based on both the general literature on virtual schooling and the research on virtual schooling.

A systematic review of the literature in $\mathrm{K}-12$ online learning provides a history of this new field of inquiry as well as a context for decision-making. Content analysis of the documents, such as metasynthesis, reveals the values and needs that dominate a field in its early stages (Marshall \& Rossman, 1999). Content analysis is also used to study distance education at the level of the course, across programs, and within the literature. Recent studies have analyzed the content of titles, authors, and abstracts of distance education articles (e.g., Ritzhaupt, et al, 2007; Rourke \& Szabo, 2002).

This metasynthesis commenced with a description of the literature base and its purposes. Template construction afforded both a classification of the literature and its meanings and messages. The categories for the template were drawn from current emphases within the field. The broad themes were the models of virtual schooling (seven categories), the roles of professionals in virtual schools (seven categories), benefits and challenges of virtual schooling (ten categories), adopted standards for virtual school courses (six categories), and adopted 
standards for virtual school teaching (thirteen categories). Documents were coded according to whether they address each category. This coding matrix was consistent with the broad to narrow classification used in template analysis. The categories revealed patterns of an emerging and maturing field of educational study. An inductive process was applied to the categories to draw inferences about the body of literature and about practice in the field (Merriam, 1998).

From an initial sample of over 500 literature sources, 226 documents met the inclusion criteria of relating directly to K-12 online learning and being openly Internet-accessible. The documents included refereed journal articles and conference papers, books and chapters, evaluation reports, dissertations, and online publications. The decision to use only open access documents was made for two reasons. The initial search of literature revealed that individuals outside of the academy authored the majority of documents; thus, the authors may not have regular or free access to subscription-based publications. Also, because the authors were interested in presenting this paper to the practitioner community, we wanted to ensure that this audience was able to access the documents on which our metasynthesis was based. An additional consideration in reviewing the literature of a rapidly-changing field like K-12 online learning was to account for effective practices that emerged from practitioners and evaluators before they were studied and published by the researcher community. Although the literature describing K-12 distance education reached back to the 1930s, the first uses of online learning and virtual schooling only began to appear in 1997. The pace of research and other documentation of K-12 online learning rose steadily from 1997 through 2008 across all document types. Each document was reviewed by two of the three coders. The individual coder used an MS Excel spreadsheet to indicate the presence or absence of a particular theme in the document. After the three coders completed their coding, the spreadsheets were compiled. There was $85 \%$ inter-coder agreement. The emergent categories and inferences from this body of work follow.

\section{Results}

The results of our metasynthesis were organized according to the five thematic areas that we identified in the methodology. The first theme of analysis that we considered was the type of virtual school. We utilized an inclusive combination of Clark's (2001) and Watson et al.'s (2004) categories to account for all identified and accepted categories of virtual schools.

\section{Table 5}

Percentage of Literature about Different Types of Virtual Schools

\begin{tabular}{|l|l|}
\hline Type of Virtual School & Percent of Literature \\
\hline Statewide & 53 \\
\hline University & 15 \\
\hline Consortium, multi-district & 38 \\
\hline Single-district, LEA & 32 \\
\hline Charter & 26 \\
\hline
\end{tabular}




\begin{tabular}{|l|l|}
\hline Private & 13 \\
\hline For-profit provider & 15 \\
\hline Other & 7 \\
\hline
\end{tabular}

The literature reflected a great deal of variety in the types of virtual schools that operated in North America; there was likewise a sizeable quantity of literature about each category of virtual schools. A smaller percentage of literature focused upon university, private, and for-profit provider virtual schools, which we attributed to the fact that these categories of virtual schools make up a smaller percentage of the virtual school community. The higher percentage of statewide and consortium/multi-district virtual schools was likely related to the fact that these two forms of virtual schooling were among the first to appear in North America and have a history established over the past decade.

As of fall 2007, only eight US states had neither multi-district full-time nor multi-district supplemental virtual school programs (Watson \& Ryan, 2007). Since then, Wyoming has announced plans to implement a state virtual school, and several other states have expanded their virtual school. The lines between public and private virtual schools has blurred as public online schools choose to become franchises for private course vendors. Virtual schooling has also been growing in Canada as more rural districts in Western Canada and more districts throughout the populous province of Ontario become involved in consortium like the Ontario Learning Consortium (see http://oelc.ca/) (O'Haire, Froese-Germain, \& Lane-De Baie, 2003). The literature has not yet addressed the relative efficacy of teacher-developed, school-developed, and vendordeveloped courses.

The second theme we analyzed was the professional role addressed in the document's findings and/or recommendations: instructors, support staff (tutors, technical support, guidance, media specialists, etc.), administrative/management, or course designer/developer. These categories originated in the virtual school professional preparation and development spectrum and continua developed for Professional Development for Virtual Schooling and Online Learning (available at http://www.nacol.org/docs/NACOL_PDforVSandOlnLrng.pdf ).

\section{Table 6}

Percentage of Literature about Various Levels of Impact

\begin{tabular}{|l|l|}
\hline Level of impact & Percent of Literature \\
\hline Teacher & 83 \\
\hline Designer & 33 \\
\hline Site facilitator & 34 \\
\hline Administrator & 54 \\
\hline Guidance counselor & 15 \\
\hline Technology coordinator & 20 \\
\hline
\end{tabular}


As noted earlier, the literature about virtual schooling largely focused upon descriptive work that often precedes experimentation in most new fields. The high percentage of literature related to the roles of teachers and administrators supports this belief, as much of this literature concentrated on the practice of virtual schooling and its implementation within the K-12 context. Indeed, the success of any school hinges on the educators who are in direct contact with students and on the administrators who support them (Darling-Hammond, 2000). Other support personnel including media specialists and site facilitators are pivotal to the success of schools (Lance, 2005; Kleiman, 2007) but have a less central role (Cavanaugh \& Cavanaugh, 2007). Therefore the roles of teachers and administrators received the majority of the scrutiny, while the impact of other professionals was just beginning to be explored.

The third thematic area pertained to the benefits and challenges that had been identified by Barbour and Reeves (2009) in their review of the literature.

\section{Table 7}

\section{Percentage of Literature about Various Benefits and Challenges}

\begin{tabular}{|l|l|}
\hline Benefit or Challenge & Percent of Literature \\
\hline Motivation & 35 \\
\hline Expanding educational access & 60 \\
\hline High quality learning opportunity & 45 \\
\hline Improving student outcomes and skills & 38 \\
\hline Educational choice & 33 \\
\hline Administrative efficiency & 22 \\
\hline Start-up costs & 37 \\
\hline Access issues & 41 \\
\hline Approval/accreditation & 22 \\
\hline Student readiness/retention & 27 \\
\hline
\end{tabular}

Based upon this analysis, much of the literature about the benefits of virtual schooling was focused upon the promise of virtual schooling and its initial rationale for implementation (i.e., the ability to expand access to educational opportunities to students in a variety of jurisdictions or the opportunity to provide high quality learning through virtual schooling). On the other hand, the literature related to the challenges of virtual schooling was focused upon largely administrative issues (i.e., the high start-up costs associated with virtual schools, access issues surrounding the digital divide).

The promise of virtual schooling as the focus of the benefits-related literature was noteworthy because the literature about the advantages of online learning generally was mixed. For example, there was no agreement in the education community or the public that online learning provides 
high quality learning experiences at any level. Reeves (2003) concluded that there is almost no evidence to support the claim that instructors who adopt new and emerging technologies also adopt new pedagogy. Further, Herrington, Reeves, and Oliver (2005) concluded that commercial course management systems restrict most instructors to the delivery of information rather than to the provision of engaging, authentic learning experiences. So although virtual schools may facilitate better instruction than the traditional classroom, there is no guarantee that this will occur.

The fourth theme corresponded with NACOL's National Standards for Quality Online Courses (available http://www.nacol.org/nationalstandards/NACOL\%20Standards\%20Quality\%20Online\%20Cours es\%202007.pdf ). Rather than using the individual standards as variables, we chose to code the standard areas. For example, the standard area of content included the following specific standards: clear and measurable objectives; alignment with content standards; alignment with required assessments; sufficient rigor, breadth, depth; integrated ICT skills; clear, complete overview and syllabus; requirements consistent with goals; information about communication with instructor; copyright issues addressed; clear expectations regarding academic integrity, netiquette; clear privacy policies; instructor resources included; and assignment and assessment keys included. We coded whether the document addresses the following online course standard areas: content, design, assessment, technology, management, and/or 21 st century skills. While it may be revealing to explore the presence of each individual standard in the literature, the body of literature appeared too limited for such examination at this time.

\section{Table 8}

Percentage of Literature about Online Course Standard Areas

\begin{tabular}{|l|l|}
\hline Online Course Standard Area & Percent of Literature \\
\hline Content & 53 \\
\hline Design & 43 \\
\hline Assessment & 52 \\
\hline Technology & 78 \\
\hline Management & 33 \\
\hline $21^{\text {st }}$ century skills & 18 \\
\hline
\end{tabular}

Unlike the majority of themes we analyzed, this theme had a considerable percentage of literature distributed across each of the categories. The amount of literature concentrated on the technology standard area was clearly dominant, understandably so for an educational enterprise mediated entirely by technology. Apart from technology, approximately one half of the literature touched upon the standard areas related to course content and design. The lower percentage for the $21^{\text {st }}$ century skills standard area may be related to the fact that the Partnership for 21st Century Skills 
(see http://www.21stcenturyskills.org/ ) only began in 2004, which reflected approximately the final four years of the twelve year time frame considered in our analysis.

Across virtual schools, course-level decisions are not made in uniform ways or in ways that resemble such decision-making in physical schools. A continuum of course development responsibility is evident in virtual schooling. At one end, teachers and/or designers make all content and design decisions at the school level. At the other end, vendors make all content and design decisions, and the role of the schools is to purchase and distribute courses to students. Schools select their level of involvement in course development based on personnel, funding, time, and other factors (Cavalluzzo, 2004).

The final thematic area corresponded with NACOL's National Standards for Quality Online Teaching (available

at http://www.nacol.org/nationalstandards/NACOL\%20Standards\%20Quality\%20Online\%20Teachi ng.pdf). As with the previous theme, we coded for the broad standard topic and not the individual standards within each area.

\section{Table 9}

Percentage of Literature about Online Teaching Standards

\begin{tabular}{|l|l|}
\hline Online Teaching Standard & Percent of Literature \\
\hline Teaching A-Credentials & 37 \\
\hline Teaching B-Tech Skills & 20 \\
\hline Teaching C-Strategies-active & 43 \\
\hline Teaching D-Leadership, feedback & 49 \\
\hline Teaching E-Legal, ethical, safety & 8 \\
\hline Teaching F-Experiential OLL & 5 \\
\hline Teaching G-Special Needs & 36 \\
\hline Teaching H-OL Assessment & 27 \\
\hline Teaching I-Goals \& Standards & 42 \\
\hline Teaching J-Data in Instruction & 14 \\
\hline Teaching K-Frequent assessment & 7 \\
\hline Teaching L-Collaborate w/colleagues & 17 \\
\hline Teaching M-Media \& materials for education & 30 \\
\hline
\end{tabular}

The most frequently referenced teaching standards in the literature related to the core behaviors of online student-teacher interaction: use of active learning strategies and feedback to students. These standards were followed in frequency by the three that are related to policy and compliance: goals and standards, addressing the needs of all learners, and teaching credentials. The next group of three standards addressed materials and technology, followed by two standards that addressed professional behavior: collaboration with colleagues and use of data to drive 
instruction. Providing frequent meaningful feedback to students and preparing active learning experiences were accepted as critical elements in both distance and face-to-face teaching (Jonassen, et al., 2008; Moore, 2007), so it was no surprise that they figure prominently in the literature about virtual schools.

\section{Conclusions and Implications}

To date, the literature on virtual schooling has concentrated upon first defining and then describing the benefits and the challenges of K-12 online learning. The research in the field in the earlier years (i.e., 1990s) focused on the effectiveness of virtual schooling by comparing it to traditional schooling and issues surrounding student readiness for and retention in virtual schooling. In recent years (i.e., post-2000), the growing body of literature shifted to a refined description of practice and outcomes in virtual schools. Our analysis of the open access literature indicated that a majority of that literature focused on statewide and consortium/multi-district virtual schools, the roles of teachers and administrators, the promise of virtual schooling and its initial rationale for implementation, administrative challenges, the technology utilized, and interaction with students.

However, the amount of empirical research was still limited. Based on the limited research included in our metasynthesis and in our review of the literature for the preparation of this manuscript, we have identified areas for future research. The first area is to establish best practices for online teaching strategies. Dipietro et al. (2008) was one of the few studies that examined effective asynchronous teaching strategies in virtual schooling (Cavanaugh, 2007; Clark, 2007). Some of the literature provided personal accounts of strategies that teachers at the FLVS and the VHS find useful (Elbaum, McIntyre, \& Smith, 2002; Johnston, 2004; Johnston \& Mitchell, 2000; Pape, Adams \& Ribeiro, 2005; Zucker \& Kozma, 2003), but there has not been systematic research into the best practices of virtual school teaching strategies, particularly asynchronous teaching strategies (Hill, Wiley, Nelson \& Han, 2004; Rice, 2006).

The second area is to improve upon the identification of characteristics that are necessary for adolescents to be successful in online learning environments and to provide remediation for students who are lacking these characteristics. The range of students enrolling in online learning opportunities is expanding (Barbour \& Mulcahy, 2007; Cavanaugh, 2007). Yet the ability of virtual schools to support a broad range of student abilities appears to be limited. After describing the promising results associated with the use of the Educational Success Prediction Instrument (ESPRI), Roblyer (2005) stated that the next step in this line of inquiry is to create materials to assist in the remediation of those students whose ESPRI results indicated potential for problems. Rice (2006) also suggested that researchers need to continue the research into and development of prediction tools, such as the ESPRI.

The third area concerns how virtual school and brick-and-mortar school personnel can encourage more interaction between in-school and online classmates. Interaction was one of the key components to create a learning community for virtual school students (Barbour, 2007). Research 
into the field of learning communities in online learning environments has been growing over the past decade (e.g., Alavi \& Dufner, 2004; Berg, 1999; Carabajal, LaPointe, \& Gunawardena, 2003; Dirkx \& Smith, 2004; Fung, 2004; Hill, 2002; Hill, Raven, \& Han, 2007; Kollock, 1998; McAlpine, 2000; Rovai, 2001; Stacey, 1999). However, like the literature on distance education and online learning in general, the research into online learning communities is almost exclusively focused upon adult populations (including all of the references cited above). There is a shortage of research exploring the development of K-12 online learning communities.

Finally, the fourth area is to examine the quality of student learning experiences in virtual school environments, especially those of lower performing students. As stated earlier, the range of students enrolling in online learning opportunities is expanding. Scherer (2006) indicated that as the range of students with new and different needs expands, research is required to ensure that online learning is a realistic and accessible opportunity. Research studies investigating the online learning experience for lower performing students will assist personnel to design appropriate supports as this particular population of students continues to grow within virtual schools. 
Research and Practice in K-12 Online Learning: A Review of Open Access Literature

Cavanaugh, Barbour, and Clark

\section{References}

Alavi, M., \& Dufner, D. (2004). Technology-mediated collaborative learning: A research perspective. In S. R. Hiltz \& R. G. Goldman (Eds.), Learning together online (pp. 191213). Mahwah, NJ: Lawrence Erlbaum Associates, Inc.

$\mathrm{Au}$, W. (2007). High-stakes testing and curricular control: A qualitative metasynthesis. Educational Researcher, 36(5), 258-267.

Baker, J. D., Bouras, C., Hartwig, S. M., \& McNair, E. R. (2005). K12, Inc. and the Colorado Virtual Academy: A virtual charter school. In Z. L. Berge \& T. Clark (Eds.), Virtual schools: Planning for success (pp. 133-142). New York: Teachers College Press.

Ballas, F. A., \& Belyk, D. (2000). Student achievement and performance levels in online education research study. Red Deer, AB: Schollie Research \& Consulting. Retrieved July 31, 2005 from http://www.ataoc.ca/files/pdf/AOCresearch full report.pdf

Barbour, M. K. \& Mulcahy, D. (2006). An inquiry into retention and achievement differences in campus based and web based AP courses. Rural Educator, 27(3), 8-12.

Barbour, M. K., \& Mulcahy, D. (October 2008). How are they doing? Examining student achievement in virtual schooling. Education in Rural Australia, 18(2), 63-74.

Barbour, M. K., \& Reeves, T. C. (2009). The reality of virtual schools: A review of the literature. Computers and Education, 52(2), 402-416.

Barker, K., Wendel, T., \& Richmond, M. (1999). Linking the literature: School effectiveness and virtual schools. Vancouver, BC: FuturEd. Retrieved July 31, 2005, from http://www.canlearn.ca/planning/pro/support/pdf/ComparingVirtualConventional.pdf

Barker, K., \& Wendel, T. (2001). e-Learning: Studying Canada's virtual secondary schools. Kelowna, BC: Society for the Advancement of Excellence in Education. Retrieved July 31, 2005, from http://www.saee.ca/pdfs/006.pdf

Berg, G. A. (1999). Community in distance learning through virtual teams. Educational Technology Review, 1(2), 23-29.

Berge, Z. L., \& Clark, T. (2005). Virtual schools: Planning for success. New York, NY: Teachers College Press.

Bigbie, C., \& McCarroll, W. (2000). The Florida high school evaluation 1999-2000 report. Tallahassee, FL: Florida State University. Retrieved February 25, 2007, from 
Research and Practice in K-12 Online Learning: A Review of Open Access Literature

Cavanaugh, Barbour, and Clark

http://www.flvs.net/educators/documents/pdf/archived_evals/FLVS\%20Annual\%20Eval uations/99-2000/99-2000\%20Year\%20End\%20Evaluation.pdf

Bransford, J. D., Brown, A. L. \& Cocking, R. R, (2003). How people learn: Brain, mind, experience and school. Washington, DC: National Academy of Sciences.

Bright, B. P. (1989). Epistemological vandalism: Psychology in the study of adult education. In B. P. Bright (Ed.), Theory and practice in the study of adult education: The epistemological debate (pp. 34-64). London, U.K.: Routledge.

Butz, C. (2004). Parent and student satisfaction with online education at the elementary and secondary levels. Unpublished dissertation, University of Nevada at Las Vegas, Las Vegas, NV.

Carabajal, K., LaPointe, D., \& Gunawardena, C. N. (2003). Group development in online learning communities. In M. G. Moore \& W. G. Anderson (Eds.), Handbook of distance education (pp. 217-234). Mahwah, NJ: Lawrence Erlbaum Associates, Inc.

Cavalluzzo, L. (2004). Organizational models for online education. Alexandria, VA: CNA Corporation. Retrieved August 9, 2006, from: www.cna.org/documents/P\&P109.pdf

Cavanaugh, T. \& Cavanaugh, C. (2007). Virtual Schools and the School Library. In C. Crawford et al. (Eds.), Proceedings of Society for Information Technology and Teacher Education International Conference 2007 (pp. 251-256). Chesapeake, VA: AACE.

Cavanaugh, C. \& Clark, T. (2007). The landscape of K-12 online learning. In Cavanaugh, C. \& Blomeyer, B. (Eds.), What works in K-12 online learning. Eugene, OR: International Society for Technology in Education.

Cavanaugh, C. S., Ferdig, R., Johnson, S. D., Lowes, S., Smith, R., \& Blomeyer, R. L. (2006, November). What works in K-12 online learning. Paper presented at the annual Virtual School Symposium, Plano, TX.

Cavanaugh, C. (2001). The effectiveness of interactive distance education technologies in K-12 learning: A meta-analysis. International Journal of Educational Telecommunications, 7(1), 73-88.

Cavanaugh, C., Gillan, K. J., Bosnick, J., Hess, M., \& Scott, H. (2005). Succeeding at the gateway: Secondary algebra learning in the virtual school. Jacksonville, FL: University of North Florida. 
Cavanaugh, C. (2007). Effectiveness of K-12 online learning. In M. G. Moore (Ed.), Handbook of distance education (2nd ed., pp. 157-168). Mahwah, NJ: Lawrence Erlbaum Associates, Inc.

Clark, T. (2003). Virtual and distance education in American schools. In M. G. Moore (Ed.), Handbook of distance education (pp. 673-699-168). Mahwah, NJ: Lawrence Erlbaum Page|16 Associates, Inc.

Clark, T. (2000). Virtual high schools: State of the states - A study of virtual high school planning and preparation in the United States: Center for the Application of Information Technologies, Western Illinois University. Retrieved July 4, 2005, from http://www.imsa.edu/programs/ivhs/pdfs/stateofstates.pdf

Clark, T. (2001). Virtual schools: Trends and issues - A study of virtual schools in the United States. San Francisco, CA: Western Regional Educational Laboratories. Retrieved July 4, 2005, from http://www.wested.org/online pubs/virtualschools.pdf

Clark, T., Lewis, E., Oyer, E., \& Schreiber, J. (2002). Illinois virtual high school evaluation, 2001-2002. Carbondale, IL: TA Consulting and Southern Illinois University. Retrieved July 4, 2005, from http://www2.imsa.edu/programs/ivhs/pdfs/IVHS FinalRpt.pdf

Clark, T. (2007). Virtual and distance education in North American schools. In M. G. Moore (Ed.), Handbook of distance education (2nd ed., pp. 473-490). Mahwah, NJ: Lawrence Erlbaum Associates, Inc.

Cuban, L. (2001). Oversold and underused: Computers in the classroom. Cambridge, MA: Harvard University Press.

Darling-Hammond, L. (2000). Teacher quality and student achievement: a review of state policy evidence. Education Policy Analysis Archives, 8(1).

DiPietro, M., Ferdig, R. E., Black, E. W. \& Preston, M. (2008). Best practices in teaching K-12 online: Lessons learned from Michigan Virtual School teachers._Journal of Interactive Online Learning, 7(1). Retrieved on May 30, 2008, from http://www.ncolr.org/jiol/issues/getfile.cfm?volID=7\&IssueID=22\&ArticleID=113

Dirkx, J. M., \& Smith, R. O. (2004). Thinking out of a bowl of spaghetti: Learning to learn in online collaborative groups. In T. S. Roberts (Ed.), Online collaborative learning: Theory and practice (pp. 132-159). Hershey, PA: Information Science Publishing.

Edelson, P. J., \& Pittman, V. V. (2001). E-Learning in the United States: New directions and opportunities for university continuing education. Global E-Journal of Open, Flexible \& Distance Education, 1(1), 71-83. 
Elbaum, B., \& Tinker, R. (1997). A review of secondary netcourses and virtual schools. Concord, MA: Concord Consortium.

Elbaum, B., McIntyre, C., \& Smith, A. (2002). Essential elements: Prepare, design, and teach your online course. Madison, WI: Atwood Publishing.

Espinoza, C., Dove, T., Zucker, A., \& Kozma, R. (1999). An evaluation of the Virtual High School after two years in operation. Arlington, VA: SRI International. Retrieved July 31, 2005, from http://ctl.sri.com/publications/downloads/evalvhs2yrs.pdf

Freedman, G., Darrow, R., Watson, J., \& Lorenzo, G. (2002). California virtual school report: A national survey of virtual education practice and policy with recommendations for the State of California: Lorenzo Associates, Inc. Retrieved July 4, 2005, from http://www.edpath.com/images/VHSReport.pdf

Fulton, K. (2002a). Guide to online high school courses. Washington, DC: National Education Association. Retrieved July 4, 2005, from https://www.nea.org/technology/images/02onlinecourses.pdf

Fulton, K. (2002b). Preserving principles of public education in an online world. Washington, DC: Center on Education Policy. Retrieved November 28, 2005, from http://www.ctredpol.org/democracypublicschools/preserving_principles_online_world_fu $\underline{11 . p d f}$

Fung, Y. H. (2004). Collaborative online learning: Interaction patterns and limiting factors. Open Learning, 19(2), 135-149.

Hassell, B. C., \& Terrell, M. G. (2004). How can virtual schools be a vibrant part of meeting the choice provisions of the No Child Left Behind Act? Virtual School Report. Retrieved November 11, 2006, from http://www.connectionsacademy.com/PDFs/VirtualNews704.pdf

Haughey, M., \& Muirhead, W. (1999). On-line learning: Best practices for Alberta school jurisdictions. Edmonton, AB: Government of Alberta. Retrieved July 31, 2005, from http://www.phrd.ab.ca/technology/best_practices/on-line-learning.pdf

Hernandez, F. J. (2005). Equity and access: The promise of virtual schools. In Z. L. Berge \& T. Clark (Eds.), Virtual schools: Planning for success (pp. 20-34). New York, NY: Teachers College Press.

Herrington, J., Reeves, T. C., \& Oliver, R. (2005). Online learning as information delivery: Digital myopia. Journal of Interactive Learning Research, 16(4), 353-367. 
Hill, J. R. (2002). Overcoming obstacles and creating connections: Community building in webbased learning environments. Journal of Computing in Higher Education, 14(1), 67-86.

Hill, J. R., Raven, A., \& Han, S. (2007). Connections in web-based learning environments: A research-based model for community building. In R. Luppicini (Ed.), Learning Page|18 communities in education (pp. 153-168). Greenwich, CT: Information Age Publishing.

Hill, J. R., Wiley, D., Nelson, L. M., \& Han, S. (2004). Exploring research on Internet-based learning: From infrastructure to interactions. In D. H. Jonassen (Ed.), Handbook of research on educational communications and technology (2nd ed.). Mahwah, NJ: Lawrence Erlbaum Associates, Publishers.

Johnston, S. (2004). Teaching any time, any place, any pace. In C. Cavanaugh (Ed.), Development and management of virtual schools: Issues and trends (pp. 116-134). Hershey, PA: Idea Group, Inc.

Johnston, S., \& Mitchell, M. (2000). Teaching the FHS way. Multimedia Schools, 7(4), 52-55.

Jonassen, D., Howland, J., Marra, R.M. \& Crismond, D. (2008). Meaningful learning with technology $\left(3^{\text {rd }}\right.$ ed). Upper Saddle River, NJ: Pearson/Merrill Prentice Hall.

Keegan, D. (1996). Foundations of distance education. London: Routledge.

Keeler, C. (2003). Developing and using an instrument to describe instructional design elements of high school online courses. Unpublished doctoral dissertation, University of Oregon, Eugene.

Kellogg, L., \& Politoski, K. (2002). Virtual schools across America: Trends in K-12 online education. Los Angeles, CA: Peak Group Research Corporation.

Knowles, M. S. (1970). The modern practice of adult education: Andragogy vs. pedagogy. New York, NY: Association Press.

Kollock, P. (1998). Design principles for online communities. PC Update, 15(5), 58-60.

Kozma, R., Zucker, A., \& Espinoza, C. (1998). An evaluation of the Virtual High School after one year in operation. Arlington, VA: SRI International. Retrieved July 31, 2005, from http://ctl.sri.com/publications/downloads/evalvhs1yr.pdf

Lance, K. \& Loertscher, D. (2005). Powering achievement: School library media programs make a difference: The evidence. (3rd ed.). Salt Lake City, UT: Hi Willow Research and Publishing. 
Marhsall, C. \& Rossman, G. (1999). Designing qualitative research. Thousand Oaks, CA: Sage Publications.

McAlpine, I. (2000). Collaborative learning online. Distance Education, 21(1), 66-80.

McLeod, S., Hughes, J. E., Brown, R., Choi, J., \& Maeda, Y. (2005). Algebra achievement in virtual and traditional schools. Naperville, IL: Learning Point Associates.

Merriam, S. (1998). Qualitative research and case study applications in education. San Francisco: Jossey-Bass Publishers.

Moore, M. G. (1973). Toward a theory of independent learning and teaching. Journal of Higher Education, 44(12), 661-679.

Moore, M. (Ed.) (2007). Handbook of distance education, (2 ${ }^{\text {nd }}$ ed.) Mahwah, NJ: Lawrence Erlbaum.

Morris, S. (2002). Teaching and learning online: A step-by-step guide for designing an online $K$ 12 school program. Lanham, MD: Scarecrow Press Inc.

Noble, D. F. (2001). Digital diploma mills: The automation of higher education. New York: Monthly Review Press.

O’Dwyer, L., Carey, R. \& Kleiman, G. (2007). A Study of the effectiveness of the Louisiana Algebra I online course. Journal of Research on Technology in Education, 39(3), 289306.

O'Haire, N., Froese-Germain, B., \& Lane-De Baie, S. (2003). Virtual education, real educators: Issues in online learning. Ottawa, ON: The Canadian Teachers' Federation.

Pape, L., Adams, R., \& Ribeiro, C. (2005). The Virtual High School: Collaboration and online professional development. In Z. L. Berge \& T. Clark (Eds.), Virtual schools: Planning for success (pp. 118-132). New York, NY: Teachers College Press.

Postman, N. (2003). Questioning media. In M. S. Pittinsky (Ed.), The wired tower: Perspectives on the impact of the internet on higher education (pp. 181-200). Upper Saddle River, NJ: Prentice Hall.

Powell, A., \& Patrick, S. (2006). An international perspective of $K-12$ online learning: A summary of the 2006 NACOL international e-learning survey. Vienna, VA: North American Council for Online Learning. 
Research and Practice in K-12 Online Learning: A Review of Open Access Literature

Cavanaugh, Barbour, and Clark

Reeves, T. C. (2003). Storm clouds on the digital education horizon. Journal of Computing in Higher Education, 15(1), 3-26.

Rice, K. L. (2006). A comprehensive look at distance education in the K-12 context. Journal of Research on Technology in Education, 38(4), 425-448.

Ritzhaupt, A. D., Smith, P., Stewart, M. \& Barron A. E. (2007, April). Distance education as seen through the eyes of its literature: A co-word analysis. Paper presented at the annual meeting of the American Educational Research Association, April 9-13, 2007, Chicago, IL.

Roblyer, M. D. (2005). Who plays well in the virtual sandbox? Characteristics of successful online students and teachers. SIGTel Bulletin, 2.

Rourke, L. \& Szabo, M. (2002). A content analysis of the Journal of Distance Education 1986 2001. Journal of Distance Education, 17(1).

Rovai, A. P. (2001). Classroom community at a distance: A comparative analysis of two ALNbased university programs. Internet and Higher Education, 4(2), 105-118.

Russell, G. (2001). Virtual schools and educational futures. Educational Technology, 41(6), 5557.

Russell, G. (2002). Ethical concerns about virtual schools. Journal of Religious and Theological Information, 5(1), 31-47.

Russell, G. (2003). The potential and problems of virtual schooling. The Welsh Journal of Education, 12(1), 40-52.

Russell, G. (2004). The advantages and disadvantages of virtual schools. ICT in Education Journal, 7(1), 6-8.

Russell, G. (2005). The distancing question in online education. Innovate, 1(4). Retrieved July 4, 2005, from http://www.innovateonline.info/index.php?view=article\&id=13

Russell, G. (2006a). Globalization, responsibility and virtual schools. Australian Journal of Educational Technology, 50(2), 140-154.

Russell, G. (2006b). Online and virtual schooling in Europe. European Journal of Open, Distance and e-Learning (2006/I). Retrieved May 18, 2006, from http://www.eurodl.org/materials/contrib/2006/Glenn_Russell.htm 
Russo, A. (2001). E-learning everywhere. The School Administrator Web Edition. Retrieved October 28, 2006, from http://www.aasa.org/publications/saarticledetail.cfm?ItemNumber=3278\&snItemNumber $=950 \&$ tnItemNumber $=1995$

Scherer, J. (2006). Special report: Virtual high schools. San Diego, CA: Distance-Educator.com.

Setzer, J. C., \& Lewis, L. (2005). Distance education courses for public elementary and secondary school Students: 2002-03. (NCES 2005-010). Washington, DC: U. S. Department of Education, National Center for Education Statistics.

Stacey, E. (1999). Collaborative learning in an online environment. Journal of Distance Education, 14(2).

Thomas, W. R. (1999). Essential elements for web-based courses for high school students. Atlanta, GA: Southern Regional Education Board. Retrieved July 4, 2005, from http://www.sreb.org/programs/EdTech/pubs/EssentialElements/EssentialElements.pdf

Thomas, W. R. (2000). Essential principles of quality: Guidelines for web-based courses for middle and high schools. Atlanta, GA: Southern Regional Education Board. Retrieved July 4, 2005, from http://www.sreb.org/programs/EdTech/pubs/EssentialPrincipals/EssentialPrinciples.pdf

Thomas, W. R. (2003). Essential principles of high-quality online teaching: Guidelines for evaluating K-12 online teachers. Atlanta, GA: Southern Regional Education Board. $\begin{array}{llll}\text { Retrieved July 4, 2005, from } & \text { 4, }\end{array}$ http://www.sreb.org/programs/EdTech/pubs/PDF/Essential_Principles.pdf

Thorne, S. E., Jensen, I., Kearney, M. H., Noblit, G. W., \& Sandelowski, M. (2004). Qualitative metasynthesis: Reflections on methodological orientation and ideological agenda. Qualitative Health Research, 14(10), 1342-1365.

Tinker, R., \& Haavind, S. (1997). Netcourses and netseminars: Current practice and new designs. Concord, MA: Concord Consortium. Retrieved April 17, 2000, from http://www.corcord.org/pubs/pdf/netcours.pdf

Vail, K. (2001). Online learning grows up: No longer an experiment, virtual school is here to stay. Electronic School. Retrieved July 31, 2005, from http://www.electronicschool.com/2001/09/0901f1.html

Vygotsky, L. S. (1962). Thought and Language (E. Hanfmann \& G. Vakar, Trans.). Cambridge, MA: The M.I.T. Press. 
Vygotsky, L. S. (1978). Mind in society: The development of higher psychologist processes. Cambridge, MA: Harvard University Press.

Watson, J. \& Ryan, J. (2007). Keeping pace with k-12 online learning: A review of state-level policy and practice. AT\&T Foundation.

Watson, J. F., Winograd, K., \& Kalmon, S. (2004). Keeping pace with K-12 online learning: A snapshot of state-level policy and practice. Naperville, IL: Learning Point Associates.

Zucker, A. (2005). A study of student interaction and collaboration in the Virtual High School. Naperville, IL: Learning Point Associates.

Zucker, A., \& Kozma, R. (2003). The Virtual High School: Teaching generation V. New York, NY: Teachers College Press.

\footnotetext{
${ }^{\mathrm{i}}$ Some have contested the belief that children and adults learn differently (see Bransford, Brown, \& Cocking, 2003).
}

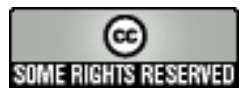

